\title{
EVALUATION OF HIGH-TEMPERATURE-INDUCED DAMAGE TO CONCRETE
}

\author{
OVREDNOTENJE VISOKOTEMPERATURNO INDUCIRANIH \\ POŠKODB BETONA
}

\author{
Bo Zhang ${ }^{1}$, Shoujun Wu ${ }^{1 *}$, Qiang Guo ${ }^{2}$, Peng Zhang ${ }^{1}$, Rufang Yao', \\ Yingxin Chen ${ }^{1}$ \\ ${ }^{1}$ College of Water Resources and Architectural Engineering, Northwest A\&F University, Yangling, Shaanxi 712100, China \\ ${ }^{2}$ Xinjiang Water Resources and Hydropower School, Wulumuqi, 23 Weihui Road, Xinjiang 830013, China
}

Prejem rokopisa - received: 2019-01-05; sprejem za objavo - accepted for publication: 2019-03-27

doi:10.17222/mit.2019.005

The evaluation of high-temperature-induced damage to an ordinary Portland cement concrete was carried out. Results showed that the uniaxial compressive strength of the concrete linearly decreased with the increasing exposure temperature. After a high-temperature exposure, the concrete was more easily deformed under loading. The as-received cement was dense and free of obvious holes. The cement and the aggregate were bonded tightly, and no cracks were observed. Above $200{ }^{\circ} \mathrm{C}$, dehydration and decomposition of calcium silicate hydrate during the high-temperature exposure led to small holes, formed in the cement, and microcracks at the bonding aggregate/cement interface. With the increasing exposure temperature, the small holes formed in the cement grew up and the microcracks located at the aggregate/cement interface gradually expanded into a coherent crack network. Above $600{ }^{\circ} \mathrm{C}$, the cement was significantly locally pulverized and the microcracks at the aggregate/cement interface were further broadened. Below $400{ }^{\circ} \mathrm{C}$, detected phases of the exposed mortar sample were the same as those of the as-received mortar. After exposures to $600{ }^{\circ} \mathrm{C}$ and $800{ }^{\circ} \mathrm{C}$, peaks of $\mathrm{CaO}$ were also detected besides the pre-existing phases. The reaction between $\mathrm{CaO}$ and $\mathrm{SiO}_{2}$ enhanced the decomposition of $\mathrm{CaCO}_{3}$ while promoting the formation of $\mathrm{Ca}_{2} \mathrm{SiO}_{4}$.

Keywords: concrete, high-temperature exposure, microstructure, phase compositions

Avtorji so raziskovali visokotemperaturno inducirane poškodbe običajnega Portland cementa. Rezultati raziskave so pokazali, da enoosna tlačna trdnost cementa linearno pada z naraščajočo temperaturo obremenitve. Po izpostavitvi betona visoki temperaturi se je le-ta pod obremenitvijo lažje deformiral. Beton v izhodnem stanju je bil gost in brez očitnih por oz. lukenj. Cement in agregati so bili trdno povezani in ni bilo opaziti razpok. Nad $200{ }^{\circ} \mathrm{C}$ je prišlo do dehidracije in razpada Ca-Si hidrata. Med visokotemperaturno obremenitvijo betona je nato prišlo do nastanka manjših lukenj v cementu in mikrorazpok na vezni meji agregati/cement. Z naraščajočo temperaturo so se nastajajoče luknje povečevale in prišlo je do širjenja mikrorazpok na vezni meji med agregati in cementom tako, da je nastala povezana mreža razpok. Pod $400{ }^{\circ} \mathrm{C}$ so avtorji zaznali enake faze $\mathrm{v}$ vzorcih termično obremenjene malte kot jih je vseboval beton v izhodnem stanju. Po njegovi termični obremenitvi na $600{ }^{\circ} \mathrm{C}$ in $800{ }^{\circ} \mathrm{C}$, so zaznali vrhove $\mathrm{CaO}$ poleg predhodnih faz. Reakcija med $\mathrm{CaO}$ in $\mathrm{SiO}_{2}$ je pospešila razpad $\mathrm{CaCO}_{3}$ in pospešila tvorbo $\mathrm{Ca}_{2} \mathrm{SiO}_{4}$.

Ključne besede: beton, izpostavljenost visoki temperaturi, mikrostruktura, fazne sestave

\section{INTRODUCTION}

Concrete construction materials are widely used in various buildings, bridges and infra-structures. However, when exposed to elevated temperatures, as in the case of fire, deterioration of mechanical properties of concrete may bring great threats to the safety of the fire-damaged structures. For example, a fire exposure reduces the structural strength and stiffness of rectangular, reinforced-concrete slab panels by heating, and highly deflected shapes of the slabs occur. ${ }^{1}$ Experimental results also confirmed that after fire, the interaction between load and high temperature caused an increase in the deformation of a specimen, while the strength and stiffness were reduced. After exposure at $600{ }^{\circ} \mathrm{C}, 800{ }^{\circ} \mathrm{C}$ and $1000{ }^{\circ} \mathrm{C}$ for $2 \mathrm{~h}$, the limit load for the frame structure decreased on $36.9 \%, 48 \%$ and $57,3 \%$, respectively. ${ }^{2}$ In

*Corresponding author's e-mail:

shoujun_wu@163.com
2003, an 8-storey reinforced-concrete (RC) frame-supported masonry structure, located in Hengyang City, China, underwent a severe fire-induced collapse accident. It was revealed that the collapse of the building due to a fire exposure significantly weakened its residual capacity and ability to redistribute gravity loads. ${ }^{3}$

The effect of a high-temperature exposure on concrete has been wildly researched. ${ }^{4-9}$ It was demonstrated that when exposed to high temperatures, water evaporation, disintegration of hydration products and aggregates, coarsening of the microstructure and an increase in the porosity can be observed in concrete. ${ }^{4,5}$ Most of all, with the increasing temperature, the strength and elastic modulus of concrete became lower and lower. ${ }^{6,7} \mathrm{~A}$ study on the microstructure of concrete at high temperatures revealed that microcracks initiated around the boundaries of aggregates and propagated with the increasing temperature. Microcracks in cement pastes and concretes consisting of mortar mixed with sand were deformed at about $200{ }^{\circ} \mathrm{C} .{ }^{8}$ However, the research on the 
Table 1: Gradation of the sand

\begin{tabular}{|c|c|c|c|c|c|c|c|}
\hline Sieve size $(\mathrm{mm})$ & 4.75 & 2.36 & 1.18 & 0.6 & 0.3 & 0.15 & sieve bottom \\
\hline Cumulative sieve residue $(\%)$ & 4.6 & 15.0 & 26.0 & 58.8 & 91.6 & 98.2 & 100 \\
\hline
\end{tabular}

effect of high temperatures on the microstructural change of concrete is mainly focused on microcracks, ${ }^{8,9}$ while reports on the micromorphological change of cement are lacking.

On the other hand, there are many reports on the thermal behaviour of hydration products or the change in the phase compositions in ordinary Portland cement during heating. It was confirmed that during heating, there are a two-step loss of water from calcium silicate hydrate, dehydroxylation of calcium hydroxide and decarbonation of calcium carbonate. ${ }^{10,11} \mathrm{CaO}$ forms due to the dehydroxylation of calcium hydroxide and decarbonation of calcium carbonate. It should be noted that, at a high temperature, $\mathrm{CaO}$ can react with $\mathrm{SiO}_{2} \cdot{ }^{12}$ Thus, a reaction might occur between $\mathrm{CaO}$ and the sand in concrete that contains a large amount of quartz $\left(\mathrm{SiO}_{2}\right)$, enhancing a decomposition of the hydration products of cement. Therefore, the thermal behaviour, especially the change in the phase compositions of concrete, might differ from that of cement. However, the studies on the thermal behaviour of concrete are lacking.

In this paper, high-temperature exposure of an ordinary Portland cement concrete was conducted at $200{ }^{\circ} \mathrm{C}$, $300{ }^{\circ} \mathrm{C}, 400{ }^{\circ} \mathrm{C}, 500{ }^{\circ} \mathrm{C}, 600{ }^{\circ} \mathrm{C}, 700{ }^{\circ} \mathrm{C}$ and $800{ }^{\circ} \mathrm{C}$ for $2 \mathrm{~h}$. In order to check the microstructural changes of the concrete, especially the morphologies of cement and the interface zone between the aggregate and cement, cement-mortar samples were prepared, subsequently ground and polished before the high-temperature exposure. Our analysis and discussion focus principally on the evaluation of high-temperature-induced damage to concrete based on uniaxial compressive-strength tests, phase compositions, microstructure observation, caloric and weight changes during the heating studied with differential scanning calorimetry and a thermogravimetric analysis (DSC-TG).

\section{MATERIALS AND METHODS}

Ordinary low-alkali Portland cement (Dunshi P.032.5 R, Jidong Cement Co., Ltd., China) was used. Gravel with the size between $4.75 \mathrm{~mm}$ and $20 \mathrm{~mm}$ was used as coarse aggregates. Sand from the banks of the Weihe River was adopted as the fine aggregate. The fineness modulus of the fine aggregate was 2.79. Table 1 lists the gradation of the sand.

The mix proportions of concrete are shown in Table 2.

Table 2: Mix proportions of concrete $\left(\mathrm{kg} \mathrm{m}^{-3}\right)$

\begin{tabular}{|c|c|c|c|c|}
\hline W/C ratio & cement & water & gravel & sand \\
\hline 0.38 & 434 & 165 & 1185 & 606 \\
\hline
\end{tabular}

Cubic specimens with a nominal size of $100 \mathrm{~mm} \times$ $100 \mathrm{~mm} \times 100 \mathrm{~mm}$ were molded. The specimens were demolded $24 \mathrm{~h}$ after casting, then cured in a chamber with a relative humidity $(\mathrm{RH})$ of $95 \%$ at $20{ }^{\circ} \mathrm{C}$ for $28 \mathrm{~d}$ (days). After that, the cured samples were put into an oven to dry the internal free water at $80{ }^{\circ} \mathrm{C}$ for $5 \mathrm{~d}$ before exposure to elevated temperature.

As high temperature damages the concrete, cutting and the following grinding and polishing of the exposed samples may lead to an expansion of cracks or damage made to the aggregate, interfacial transition zone (ITZ) and cement paste or even an initiation of new cracks. In order to check the microstructural change before and after the high-temperature exposure, blocks with a size of $10 \mathrm{~mm} \times 10 \mathrm{~mm} \times 20 \mathrm{~mm}$ were molded using cement mortar, in which the gravel was replaced by fine aggregates. After having been demolded and cured in the same conditions, the blocks were finally polished with a $0.50 \mu \mathrm{m}$ diamond suspension. After that, they were dried at $80{ }^{\circ} \mathrm{C}$ for $5 \mathrm{~d}$, just as before. Moreover, the cement mortar cured and dried in the same conditions was used to check the caloric and weight changes during the heating.

The high-temperature exposure of the concrete samples and the cement-mortar blocks took place in an automatically programmed temperature-controlled electric furnace for $2 \mathrm{~h}$ at the desired temperature $200{ }^{\circ} \mathrm{C}$, $300{ }^{\circ} \mathrm{C}, 400{ }^{\circ} \mathrm{C}, 500{ }^{\circ} \mathrm{C}, 600{ }^{\circ} \mathrm{C}, 700{ }^{\circ} \mathrm{C}$ and $800{ }^{\circ} \mathrm{C}$. Seven concrete samples were tested for every exposure. After the high-temperature exposure, the specimens were taken out of the furnace and cooled in ambient air.

Uniaxial compressive-strength tests of the cubic samples before and after the high-temperature exposure was carried out on an Instron 1195 machine at room temperature $\left(25^{\circ} \mathrm{C}\right.$ and $\left.65 \% \mathrm{RH}\right)$. The loading rate was $0.05 \mathrm{~mm} \mathrm{~s}^{-1}$. The compressive strength was calculated based on the average value of the test values, selected within an error range of $10 \%$.

The phase composition of the samples was characterized using X-ray diffraction (XRD, BRUKER, D8 ADVANCE A25 X). The XRD analysis was operated at $40 \mathrm{KV}$ and $40 \mathrm{~mA}$. Step scans were taken in a range of $2 \theta=20-80^{\circ}$ with a 0.02 step, $0.01^{\circ} \mathrm{s}^{-1}$ scan speed and 2 -s exposure. The microstructure of the as-received and high-temperature-exposed blocks was checked with scanning electron microscopy (SEM, FEI Q45) equipped with EDS and an optical microscope (OM, Axio Scope A1 for materials research, Carl Zeiss Microscopy $\mathrm{GmbH}$, Germany).

Caloric and weight changes during the heating of dried cement mortar were measured using NETZSCH STA 429 CD. The measurements were conducted in air 
atmosphere, from room temperature to $1000{ }^{\circ} \mathrm{C}$, with a heating rate of $10{ }^{\circ} \mathrm{C} \mathrm{min}^{-1}$.

\section{RESULTS AND DISCUSSION}

Figure 1 shows the uniaxial compressive strength and several typical compressive strength/displacement curves for the cubic concrete samples before and after the exposure to high temperatures for $2 \mathrm{~h}$. It seems that the uniaxial compressive strength of the samples linearly decreased with the increasing exposure temperature as shown in Figure 1a. However, it should be noted that, as shown in Figure 1b, the slope of the initial ascending part of the compressive strength/displacement curves obviously decreased with the increasing exposure temperature, especially above $600{ }^{\circ} \mathrm{C}$. Moreover, the displacement corresponding to the maximum compressive load of the high-temperature-exposed samples increased with the increasing exposure temperature. Such changes in the compressive strength/displacement curves made after the high-temperature exposure indicate that the concrete becomes more easily deformed under loading.
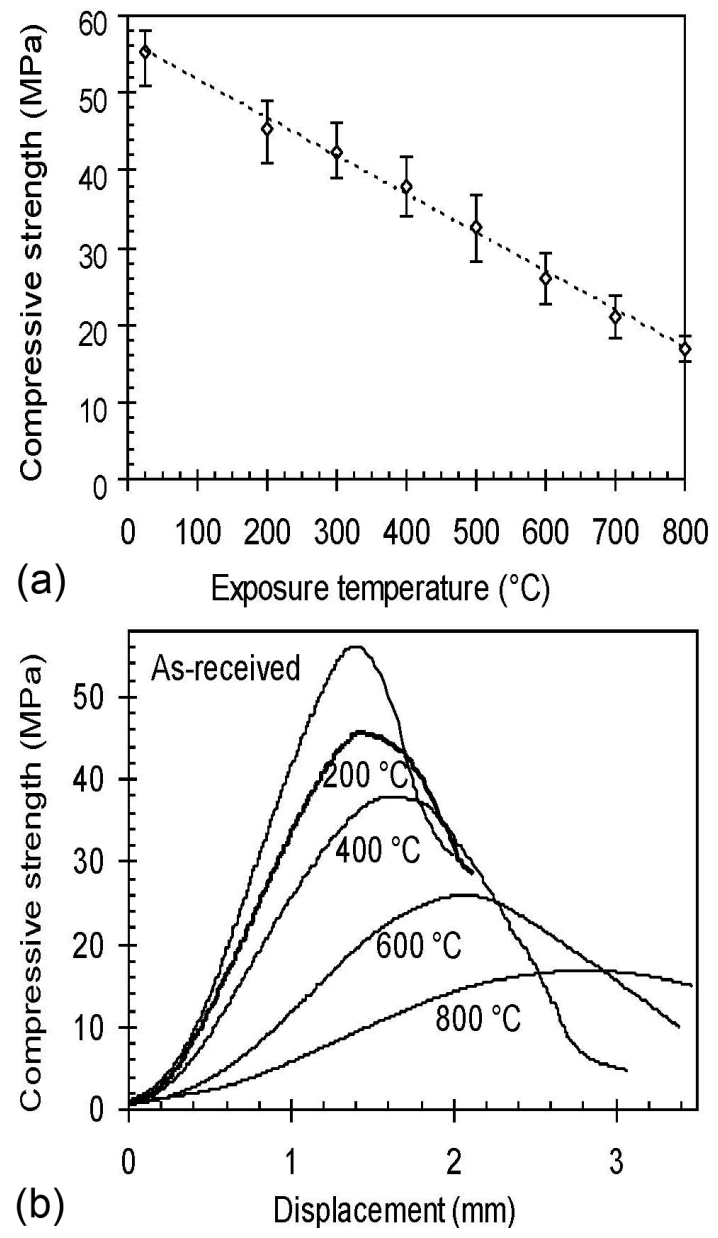

Figure 1: a) uniaxial compressive strength, b) several typical compressive strength/displacement curves of the concrete samples before and after high-temperature exposure for $2 \mathrm{~h}$
Figure 2 shows SEM micromorphologies of the cement-mortar samples before and after the exposure to high temperatures for $2 \mathrm{~h}$. It seems that the cement paste and the aggregate are tightly bonded and no cracks are observed. Moreover, the as-received cement paste is dense and free of obvious holes as shown in Figure 3. After the exposure to $200{ }^{\circ} \mathrm{C}$ for $2 \mathrm{~h}$, small holes are present in the cement paste and microcracks occur at the bonding interface of the aggregate/cement paste. With the increasing temperature, the small holes formed in the cement paste grow up and the microcracks located at the interface of the aggregate/cement paste gradually expand into a coherent crack network. After the exposure to $600{ }^{\circ} \mathrm{C}$ for $2 \mathrm{~h}$, large powder particles are locally formed in the cement paste. Moreover, it seems that the cement paste shows an obvious morphology change. After the exposure to $600{ }^{\circ} \mathrm{C}$ for $2 \mathrm{~h}$, from the, the cement paste shows a flocculent morphology with many small holes,
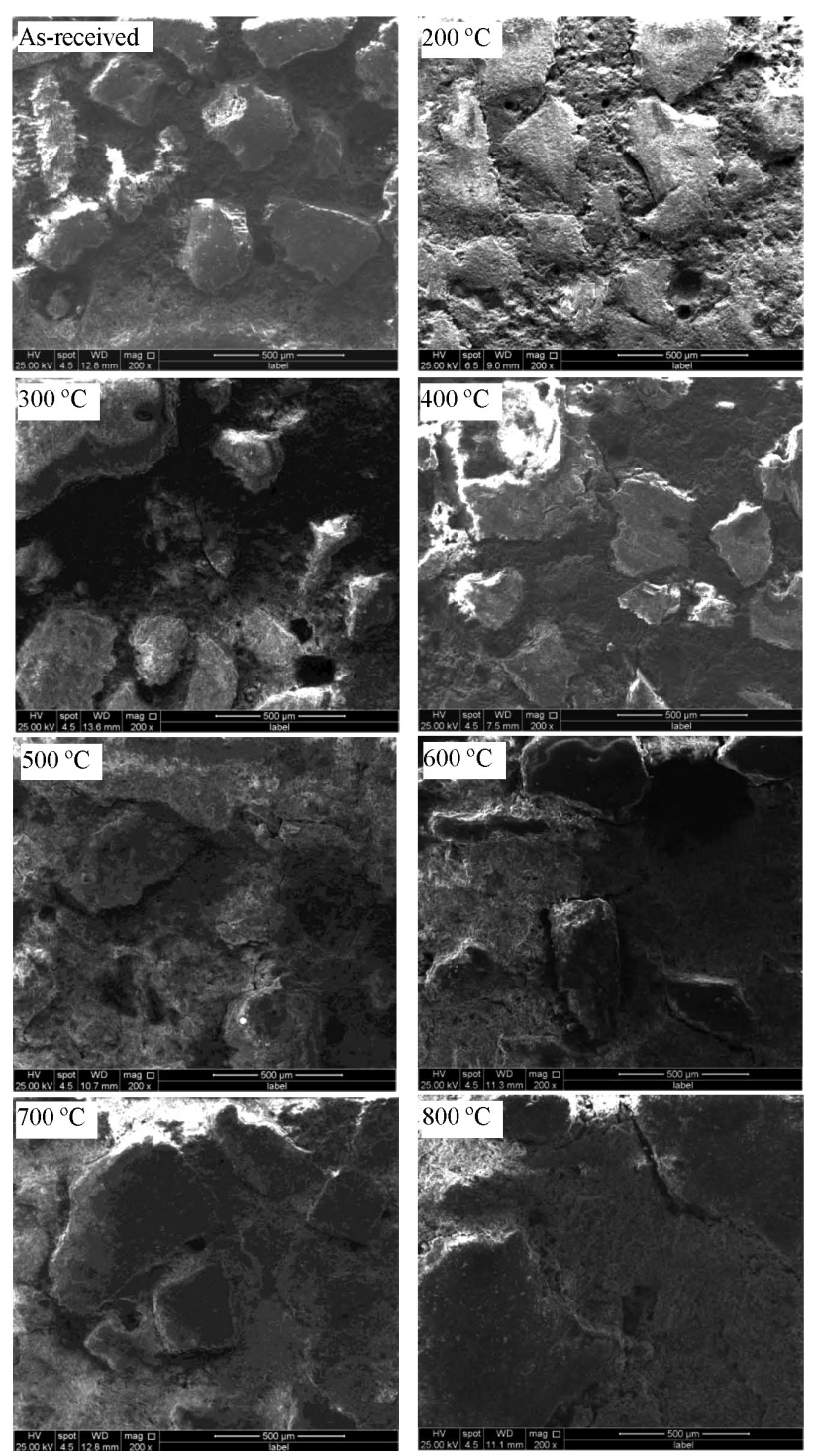

Figure 2: Micromorphologies of the samples before and after hightemperature exposure for $2 \mathrm{~h}$ 

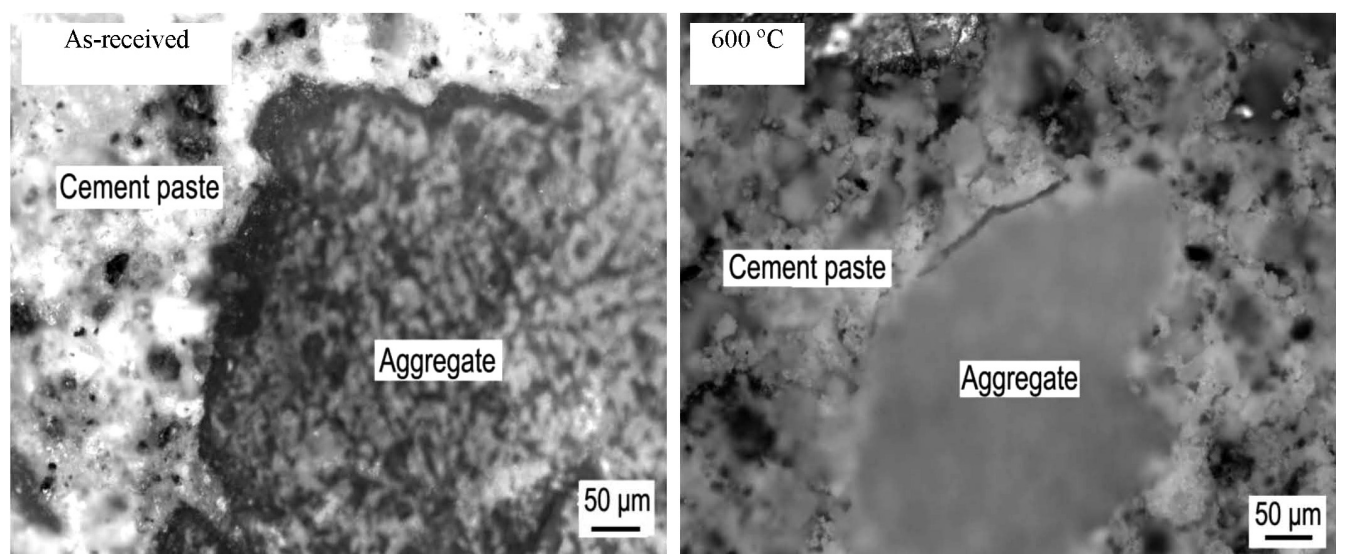

Figure 3: $\mathrm{OM}$ images of the concrete before and after exposure to $600{ }^{\circ} \mathrm{C}$ for $2 \mathrm{~h}$
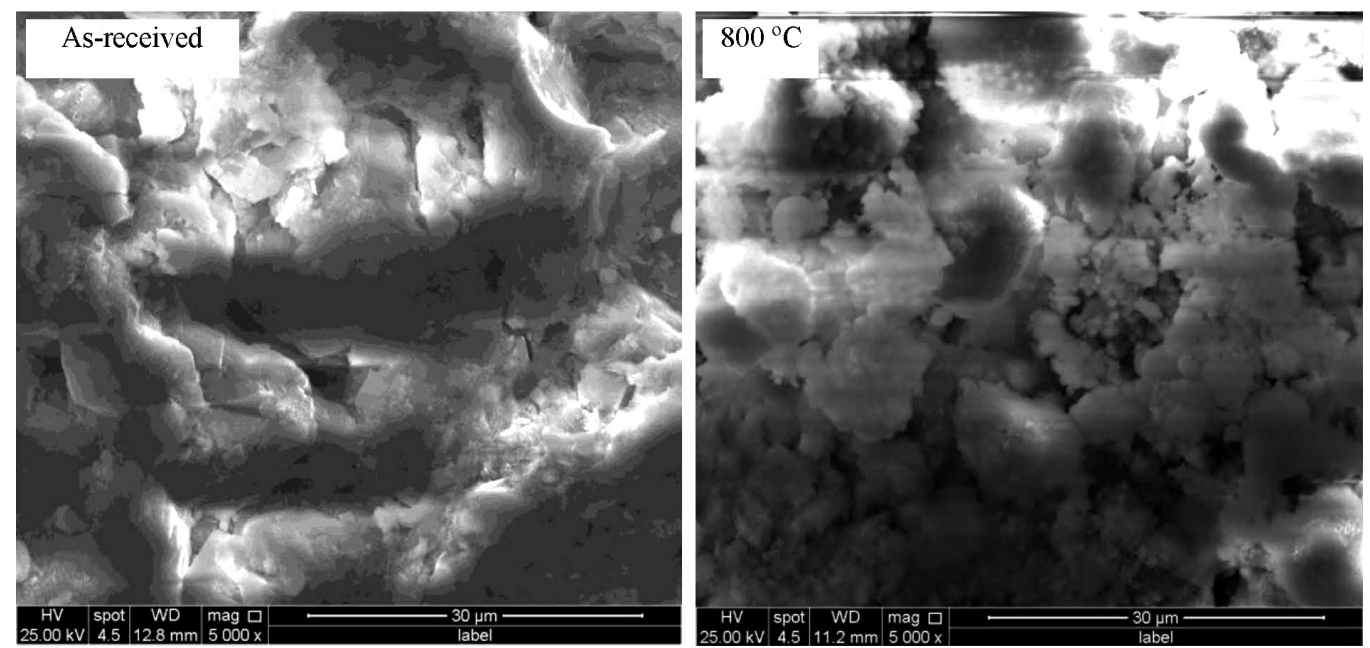

Figure 4: Magnified view of the concrete before and after exposure to $800{ }^{\circ} \mathrm{C}$ for $2 \mathrm{~h}$

as seen on the OM image in Figure 3. In addition, the cement paste becomes dim rather than glossy as the as-received cement paste. After the exposure to $800{ }^{\circ} \mathrm{C}$ for $2 \mathrm{~h}$ shown in Figure 2, the cement paste clearly becomes loose. From the magnified view of the cement paste before and after the exposure to $800{ }^{\circ} \mathrm{C}$ for $2 \mathrm{~h}$, shown in Figure 4, the morphology changes of the

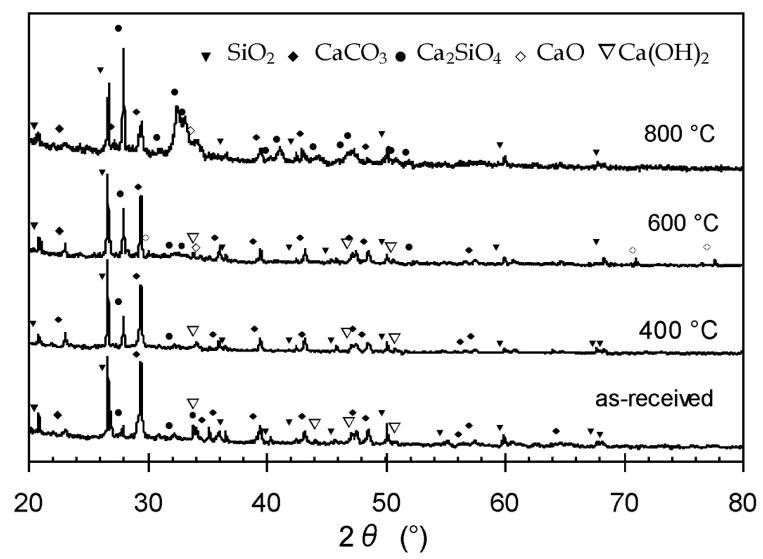

Figure 5: Several XRD patterns of the mortar samples before and after exposure to high temperatures for $2 \mathrm{~h}$ cement paste are more obvious than those after the exposure to $600{ }^{\circ} \mathrm{C}$. The morphology changes of the cement paste indicate that the composition might have changed.

Figure 5 shows several XRD patterns for the mortar samples before and after the exposures to high temperatures for $2 \mathrm{~h}$. The as-received mortar is mainly composed of $\mathrm{CaCO}_{3}, \mathrm{SiO}_{2}$ and a small amount of $\mathrm{Ca}(\mathrm{OH})_{2}$ and $\mathrm{Ca}_{2} \mathrm{SiO}_{4}$. After the exposure to $400{ }^{\circ} \mathrm{C}$, the detected phases of the mortar samples are the same as those of the as-received mortar. After the exposures to $600{ }^{\circ} \mathrm{C}$ and $800{ }^{\circ} \mathrm{C}$, peaks of $\mathrm{CaO}$ can be detected, besides $\mathrm{CaCO}_{3}$, $\mathrm{SiO}_{2}, \mathrm{Ca}(\mathrm{OH})_{2}$ and $\mathrm{Ca}_{2} \mathrm{SiO}_{4}$. The presence of $\mathrm{CaO}$ suggests that decomposition took place. It can be noted that the ratio of the intensity of the $\mathrm{CaO}, \mathrm{CaCO}_{3}$ and $\mathrm{Ca}(\mathrm{OH})_{2}$ peaks to that of the $\mathrm{SiO}_{2}$ peaks decreased with the increasing exposure temperature. On the other hand, the ratio of the intensity of the $\mathrm{Ca}_{2} \mathrm{SiO}_{4}$ peaks to that of the $\mathrm{SiO}_{2}$ peaks significantly increased with the increasing exposure temperature. The weakening of the intensity of the $\mathrm{CaCO}_{3}$ and $\mathrm{Ca}(\mathrm{OH})_{2}$ peaks and formation of $\mathrm{CaO}$ suggest that $\mathrm{CaCO}_{3}$ and $\mathrm{Ca}(\mathrm{OH})_{2}$ partially decomposed in accordance with the following reaction: ${ }^{13}$ 


$$
\begin{aligned}
\mathrm{CaCO}_{3} & \rightarrow \mathrm{CaO}+\mathrm{CO}_{2}(\mathrm{~g}) \\
\mathrm{Ca}(\mathrm{OH})_{2} & \rightarrow \mathrm{CaO}+\mathrm{H}_{2} \mathrm{O}(\mathrm{g})
\end{aligned}
$$

Furthermore, it should be noted that after the exposure to $800{ }^{\circ} \mathrm{C}$, the peaks of $\mathrm{CaO}$ obviously broadened and weakened, while those of $\mathrm{Ca}_{2} \mathrm{SiO}_{4}$ increased and broadened. Such a change of $\mathrm{CaO}$ and $\mathrm{Ca}_{2} \mathrm{SiO}_{4}$ suggests that $\mathrm{CaO}$ was partially transformed to $\mathrm{Ca}_{2} \mathrm{SiO}_{4}$.

Figure 6 shows the differential scanning calorimetry-thermogravimetric analysis (DSC-TG) curves of the mortar samples during heating in air. From the TG curves, it can be seen that a mortar sample clearly shows a small weight loss $(-0.25 \%)$ at about $152{ }^{\circ} \mathrm{C}$ and then an increased weight loss between $530{ }^{\circ} \mathrm{C}$ and $680{ }^{\circ} \mathrm{C}$ amounting to about $-2.85 \%$. On the other hand, from the DSC curves, it can be seen that a mortar sample shows a small endothermic peak at about $150{ }^{\circ} \mathrm{C}$ and about $580{ }^{\circ} \mathrm{C}$, then a significant endothermic peak between $680{ }^{\circ} \mathrm{C}$ and $895{ }^{\circ} \mathrm{C}$. The first small endothermic peak at about $150{ }^{\circ} \mathrm{C}$ is considered to be the result of dehydration reactions due to the loss of water from calcium silicate hydrate $(\mathrm{C}-\mathrm{S}-\mathrm{H}){ }^{7}$ Therefore, the mortar sample clearly exhibits a small weight loss $(-0.25 \%)$ at about $152{ }^{\circ} \mathrm{C}$, shown in the TG curve.

In addition, small holes are present in the cement paste and microcracks occur at the bonding interface of the aggregate/cement paste of the samples exposed to $200{ }^{\circ} \mathrm{C}$. It was confirmed that the decomposition of $\mathrm{Ca}(\mathrm{OH})_{2}$ usually occurs between $410{ }^{\circ} \mathrm{C}$ to $550{ }^{\circ} \mathrm{C},{ }^{14-17}$ accompanied with a weight loss of $-24.32 \%$. Therefore, the second small endothermic peak at about $580{ }^{\circ} \mathrm{C}$ is considered to be the result of the dehydration of $\mathrm{Ca}(\mathrm{OH})_{2}$. On the other hand, above $600{ }^{\circ} \mathrm{C}$, the $\mathrm{CaCO}_{3}$ decomposition is detectable using the thermal analysis/ chemical analysis coupling method ${ }^{11}$ or thermogravimetric-differential thermal analysis (TG-DTA). ${ }^{9}$ Furthermore, above $720{ }^{\circ} \mathrm{C}$, the decomposition forms active $\mathrm{CaO}$ that can react with $\mathrm{SiO}_{2}$ to form calcium silicate in accordance with the following reaction: ${ }^{12,18-20}$

$$
2 \mathrm{CaO}+\mathrm{SiO}_{2} \rightarrow \mathrm{Ca}_{2} \mathrm{SiO}_{4}
$$

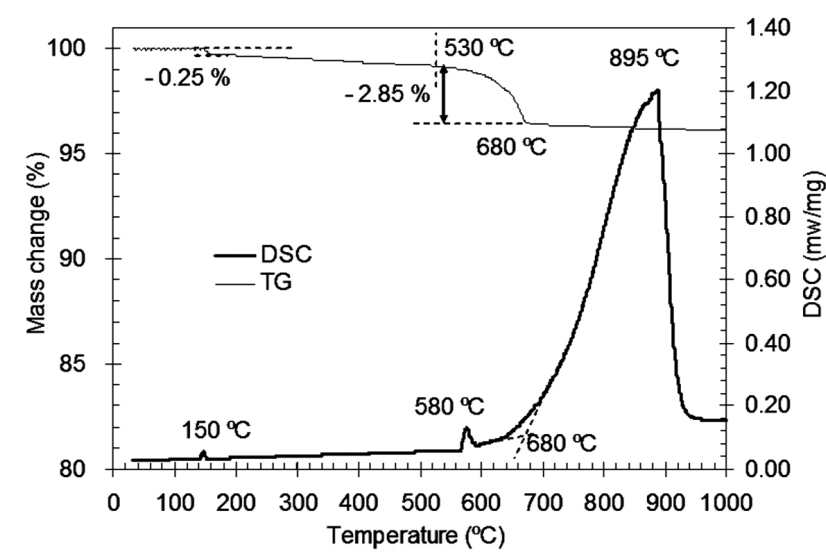

Figure 6: DSC-TG curves of the mortar samples during heating in air
Therefore, the third significant endothermic peak corresponds to the decarbonation of calcium carbonate, together with possible solid-solid phase transformations. The decomposition of $\mathrm{Ca}(\mathrm{OH})_{2}$ and $\mathrm{CaCO}_{3}$ leads to the formation of $\mathrm{CaO}$ and the mortar sample exhibits an increased weight loss between $530{ }^{\circ} \mathrm{C}$ and $680{ }^{\circ} \mathrm{C}$ as shown in the TG curves. Meanwhile, peaks of $\mathrm{CaO}$ can be detected with XRD for the samples exposed to $600{ }^{\circ} \mathrm{C}$ and $800{ }^{\circ} \mathrm{C}$. On the other hand, heating at the temperature of $800{ }^{\circ} \mathrm{C}$ leads to the transformation of $\mathrm{C}-\mathrm{S}-\mathrm{H}$ phases into calcium silicate..$^{21,22}$ Therefore, after the exposure to $800{ }^{\circ} \mathrm{C}$, the peaks of $\mathrm{CaO}$ are obviously broadened and weakened, while that of $\mathrm{Ca}_{2} \mathrm{SiO}_{4}$ is increased.

During the heating above $200{ }^{\circ} \mathrm{C}$, the dehydration is progressive, resulting in the structure of the cement paste being partially damaged. ${ }^{10}$ Therefore, though no phase change is detected after the exposure to $400{ }^{\circ} \mathrm{C}$, small holes are present, growing up in the cement paste and microcracks occur and propagate at the bonding interface of the aggregate/cement paste. Meanwhile, the strength of the cement is further decreased. Above $600{ }^{\circ} \mathrm{C}$, the decomposition of $\mathrm{Ca}(\mathrm{OH})_{2}$ and $\mathrm{CaCO}_{3}$ results in local pulverization of the cement paste and further broadening of the microcracks at the bonding interface of the aggregate/cement paste. Meanwhile, it can be concluded that the formation of $\mathrm{Ca}_{2} \mathrm{SiO}_{4}$ promotes the decomposition of $\mathrm{CaCO}_{3}$. Therefore, pulverization of the cement paste and microcracks at the bonding interface of the aggregate/cement paste become more obvious after the exposure to $800{ }^{\circ} \mathrm{C}$. As a result, the compressive strength of the concrete is further decreased with the increasing exposure temperature. On the other hand, pulverization of the cement paste makes the sample prone to deformation under loading. As a result, the slope of the initial ascending part of the compressive strength/displacement curves decreased obviously with the increasing exposure temperature, especially above $600{ }^{\circ} \mathrm{C}$.

\section{CONCLUSIONS}

The uniaxial compressive strength of the concrete linearly decreases with the increasing exposure temperature. A high-temperature exposure for $2 \mathrm{~h}$ leads to the concrete being more easily deformed under loading.

Below $400{ }^{\circ} \mathrm{C}$, the detected phases of the exposed mortar sample are the same as those of the as-received mortar. After the exposure to $600{ }^{\circ} \mathrm{C}$ and $800{ }^{\circ} \mathrm{C}$, peaks of $\mathrm{CaO}$ can also be detected, besides the pre-existing phases. The reaction between $\mathrm{CaO}$ and $\mathrm{SiO}_{2}$ enhances the decomposition of $\mathrm{CaCO}_{3}$ while promoting the formation of $\mathrm{Ca}_{2} \mathrm{SiO}_{4}$.

The as-received cement is dense and free of obvious holes. The cement and the aggregate are bonded tightly, and no cracks are observed. After the exposure to $200{ }^{\circ} \mathrm{C}$ for $2 \mathrm{~h}$, the loss of water from calcium silicate hydrate $(\mathrm{C}-\mathrm{S}-\mathrm{H})$ causes the formation of small holes in the 


\section{B. ZHANG et al.: EVALUATION OF HIGH-TEMPERATURE-INDUCED DAMAGE TO CONCRETE}

cement and microcracks at the bonding interface of the aggregate/cement. After the exposure above $400{ }^{\circ} \mathrm{C}$, the decomposition of $\mathrm{Ca}(\mathrm{OH})_{2}$ results in the formation of small holes growing up in the cement, and the microcracks located at the bonding interface of the aggregate/cement gradually expand into a coherent network of cracks. Above $600{ }^{\circ} \mathrm{C}$, the decomposition of $\mathrm{Ca}(\mathrm{OH})_{2}$ and $\mathrm{CaCO}_{3}$ results in local pulverization of the cement and further broadening of the microcracks at the bonding interface of the aggregate/cement.

\section{Acknowledgment}

The authors gratefully acknowledge the financial support from the Fundamental Research Funds for the Central Universities (QN2013050) and the fund of the Creative Research Foundation of Science and Technology on Thermostructural Composite Materials Laboratory (6142911020105).

\section{REFERENCES}

${ }^{1}$ A. S. Usmani, N. J. K. Cameron, Limit capacity of laterally restrained reinforced concrete floor slabs in fire, Cem. Concr. Compos., 26 (2004) 2, 127-140, doi:10.1016/S0958-9465(03) 00090-8

${ }^{2}$ X. Zhang, Q. Q. Shen, Z. Y. Li, S. H. Tang, Y. Luo, Experimental study on fire resistance of reinforced concrete frame structure, 2014 International Conf. on Mechanics and Civil Engineering (ICMCE-14), 1031-1037, doi:10.2991/icmce-14.2014.186

${ }^{3}$ Y. Li, W. M. Yan, X. Z. Lu, M. J. Ying, H. Guan, A case study on a fire-induced collapse accident of a reinforced concrete framesupported masonry structure, Fire Technology, 52 (2016) 3, 707-729, doi:10.1007/s10694-015-0491-0

${ }^{4}$ Q. M. Ma, R. X. Guo, Z. M. Zhao, Z. W. Lin, K. C. He, Mechanical properties of concrete at high temperature - A review, Constr. Build. Mater., 93 (2015), 371-383, doi:10.1016/j.conbuildmat.2015.05.131

${ }^{5}$ E. Tolentino, F. S. Lameiras, A. M. Gomes, C. A. R. Silva, W. L. Vasconcelos, Effects of high temperature on the residual performance of Portland cement concretes, Mater. Res., 5 (2002) 3, 301-307, doi:10.1590/S1516-14392002000300014

${ }^{6}$ T. I. Arafat, A. E. Ahmed, A. H. Al-Shaikh, Residual compressive and bond strengths of limestone aggregate concrete subjected to elevated temperatures, Mag. Concr. Res., 44 (1992) 159, 117-125, doi:10.1680/macr.1992.44.159.117

${ }^{7}$ X. J. Tan, W. Z. Chen, J. H. Wang, D. S. Yang, X. Y. Qi, Y. S. Ma, X. Wang, S. S. Ma, C. J. Li, Influence of high temperature on the residual physical and mechanical properties of foamed concrete, Constr. Build. Mater., 135 (2017), 203-211, doi:10.1016/ j.conbuildmat.2016.12.223

${ }^{8}$ X. S. Wang, B. S. Wu, Q. Y. Wang, Online SEM investigation of microcrack characteristics of concretes at various temperatures, Cem.
Concr. Res., 35 (2005) 7, 1385-1390, doi:10.1016/j.cemconres. 2004.07.015

${ }^{9}$ S. W. Yang, Z. G. Liu, Y. W. Wang, Z. R. Liu, H. J. Ba, Dynamic compressive performance of concrete exposed to high temperature based on microstructure analysis, Appl. Mech. Mater., 357-360 (2013), 1389-1394, doi:10.4028/www.scientific.net/AMM.357360.1389

${ }^{10}$ W. Sha, E. A. O’Neill, Z. Guo, Differential scanning calorimetry study of ordinary Portland cement, Cem. Concr. Res., 29 (1999) 9 , 1487-1489, doi:10.1063/1.1896489

${ }^{11}$ G. Villain, M. Thiery, G. Platret, Measurement methods of carbonation profiles in concrete: Thermogravimetry, chemical analysis and gammadensimetry, Cem. Concr. Res., 37 (2007) 8, 1182-1192, doi:10.1016/j.cemconres.2007.04.015

${ }^{12}$ N. Yamaguchi, Y. Masuda, Y. Yamada, H. Narusawa, C. H. Cheol, Y. Tamaki, T. Miyazaki, Synthesis of $\mathrm{CaO}-\mathrm{SiO}_{2}$ compounds using materials extracted from industrial wastes, Open J. Inorg. Non-Metal. Mater., 5 (2015) 1, 1-10, doi:10.4236/ojinm.2015.51001

${ }^{13}$ I. Hager, Behaviour of cement concrete at high temperature, Bull. Pol. Acad. Sci. Tech., 61 (2013) 1, 145-154, doi:10.2478/bpasts2013-0013

${ }^{14}$ J. Beaudoin, T. Sato, P. J. Tumidajski, The thermal decomposition of $\mathrm{Ca}(\mathrm{OH})_{2}$ polymorphs, Mater. Strict., 38 (2010) 11, 937-942, doi:10.1021/ja01153a547

${ }^{15}$ D. Beruto, L. Barco, A. W. Searcy, G. Spinolo, Characterization of the porous $\mathrm{CaO}$ particles formed by decomposition of $\mathrm{CaCO}_{3}$ and $\mathrm{Ca}(\mathrm{OH})_{2}$ in vacuum, J. Am. Ceram. Soc., 63 (2010) 7-8, 439-443, doi:10.1111/j.1151-2916.1980.tb10208.x

${ }^{16}$ V. S. Ramachandran, J. J. Beaudoin, P. J. Tumidajski, L. D. Mitchell, T. Sato, Thermal decomposition of nanoparticulate $\mathrm{Ca}(\mathrm{OH})_{2}$-anomalous effects, Adv. in Cem. Res., 19 (2007) 1, 1-7, doi:10.1680/adcr. 2007.19.1.1

${ }^{17}$ J. Zelić, D. Rušić, R. Krstulović, Kinetic analysis of thermal decomposition of $\mathrm{Ca}(\mathrm{OH})_{2}$ formed during hydration of commercial Portland cement by DSC, J. Therm. Anal. Calorim., 67 (2002) 3, 613-622, doi:10.1023/A:1014348603686

${ }^{18}$ K. Pimraksa, S. Hanjitsuwan, P. Chindaprasirt, Synthesis of belite cement from lignite fly ash, Ceram. Inter., 35 (2009) 6, 2415-2425, doi:10.1016/j.ceramint.2009.02.006

${ }^{19}$ K. D. Grevel, M. Schoenitz, V. Skrok, A. Navrotsky, W. Schreyer, Thermodynamic data of lawsonite and zoisite in the system $\mathrm{CaO}-\mathrm{Al}_{2} \mathrm{O}_{3}-\mathrm{SiO}_{2}-\mathrm{H}_{2} \mathrm{O}$ based on experimental phase equilibria and calorimetric work, Contrib. Mineral. Petro., 142 (2001) 3, 298-308, doi:10.1007/s004100100290

${ }^{20}$ N. Zulumyan, A. Mirgorodski, A. Isahakyan, H. Beglaryan, A. Gabrielyan, A. Terzyan, A low-temperature method of the $\beta$-wollastonite synthesis, J. Therm. Anal. Calorim., 122 (2015) 1 , 1-8, doi:10.1007/s10973-015-4752-4

${ }^{21}$ Y. Okada, H. Ishida, K. Sasaki, J. F. Young, T. Mitsuda, Characterization of $\mathrm{C}-\mathrm{S}-\mathrm{H}$ from highly reactive $\beta$-dicalcium silicate prepared from hillebrandite, J. Am. Ceram. Soc., 77 (1994) 5, 1313-1318, doi:10.1111/j.1151-2916.1994.tb05408.x

${ }^{22}$ Z. R. Gou, J. Chang, J. H. Gao, Z. Wang, In vitro bioactivity and dissolution of $\mathrm{Ca}_{2}\left(\mathrm{SiO}_{3}\right)(\mathrm{OH})_{2}$ and $\beta-\mathrm{Ca}_{2} \mathrm{SiO}_{4}$ fibers, J. Eur. Ceram. Soc., 24 (2004) 13, 3491-3497, doi:10.1016/j.jeurceramsoc.2003. 11.023 